International Journal of Civil Engineering and Technology (IJCIET)

Volume 10, Issue 03, March 2019, pp. 1348-1356, Article ID: IJCIET_10_03_131

Available online at http://www.iaeme.com/ijciet/issues.asp?JType=IJCIET \&VType $=10 \& I T y p e=03$

ISSN Print: 0976-6308 and ISSN Online: 0976-6316

\title{
THE INFLUENCE OF RAILWAY DEVELOPMENT ON THE INDONESIAN NATIONAL ECONOMY: AN INPUT-OUTPUT APPROACH
}

\author{
Hermanto Dwiatmoko
}

Faculty of Engineering, University of Mercu Buana, Jakarta Indonesia

Dadang Supriyatno

Faculty of Engineering, State University of Surabaya, Indonesia

\section{Achmad Kemal Hidayat}

Faculty of Economics and Business, University of Padjadjaran, Bandung Indonesia

\section{Ikhsan Sertiawan}

Faculty of Engineering Narotama University Surabaya Indonesia

\begin{abstract}
This paper aims to investigate the effect of railway development on the Indonesia national economy with Input-Output analysis. The data used in this study are InputOutput data from 2000 to 2010. Input-Output data analysis generates contribution, value added, intermediate input, final input, linkage and multiple impacts of railway to other modes of transportation and national economy. The result of Input-Output data analysis concludes that railway has forward and backward linkage to various sub sectors, therefore it can become superior sub-sector to increase national economic growth. The research results find out that if there is a development or investment in the railway subsector of IDR. 1 billion, this, will, therefore, give impact to: (a) the amount of economic output will increase into IDR 1.63 billion; (b) the income of the society members will become IDR. 362,5 million; (c) will upgrade the employment opportunities into 9.5 people. Accordingly, there is a need to modify the government budget (APBN) that will focus primarily on developing railway transportation, both in goods and passengers vehicles.
\end{abstract}


The Influence of Railway Development on the Indonesian National Economy: an Input-Output Approach

Keyword: Growth, Railway, Gross Domestic Product, Input-Output, Linkage, Multiplier

Cite this Article: Hermanto Dwiatmoko, Dadang Supriyatno, Achmad Kemal Hidayat and Ikhsan Sertiawan, the Influence of Railway Development on the Indonesian National Economy: an Input-Output Approach, International Journal of Civil Engineering and Technology, 10(3), 2019, pp. 1348-1356

http://www.iaeme.com/IJCIET/issues.asp?JType=IJCIET\&VType=10\&IType $=03$

\section{INTRODUCTION}

In human's life, transportation plays a very important and strategic role because the mobility of the people from one place to another requires transportation services. Along with the increasing numbers of human's needs for goods and services, it is increasingly important to have a good role of transportation mode. The transportation sector is needed to connect various areas, either by land, sea or air transportation modes. In this context transportation serves as the economic artery, because the transport can be made by the movement of people and goods. If mobility is largely facilitated by the transport system more and more often, it indicates the activity and economic development of the region that ultimately can improve the welfare of the community.

In the economic system, transportation is referred to as derived demand, meaning transportation is necessary because of other activities. Transportation needs will increase with increasing economic activity and decrease in case of economic downturn.

The economic benefits of transport infrastructure investment are long-term competitiveness, productivity, innovation, lower production prices, and higher revenues. Investment in transport infrastructure also creates thousands of jobs in the near future. A well-performing transport network opens up employment, enabling businesses to grow and lower down the price of home appliances. This will make the entrepreneurs to manage the stock of goods well and efficiently. Transportation makes it easy for suppliers to market their products, making it more cost-effective for industry to keep their production going.

Railway transport has certain characteristics and advantages, especially in its ability to transport both passengers and goods in bulk, energy saving, space-saving, high safety, low pollution (more environmentally friendly) and more efficient than road transport.

The railway system is a mass transportation that can be used for the transportation of passengers and goods in large quantities so that it's more efficient than the road transport.

Table 1. Contribution of transportation sector in the total output.

\begin{tabular}{|c|c|c|c|c|}
\hline NO. & MODA TRANSPORTASI & $\begin{array}{c}\text { GDP } \\
\text { RP. MILIAR }\end{array}$ & $\%$ GDP & $\begin{array}{c}\% \\
\text { Transportation }\end{array}$ \\
\hline 1. & Road Transport & 193.257 & 2,22 & 55,41 \\
\hline 2. & Rail Transport & 2.950 & 0,03 & 0,84 \\
\hline 3. & River, Lake and ferries & 10.222 & 0,12 & 2,93 \\
\hline 4. & Sea transport & 30.173 & 0,35 & 8,65 \\
\hline 5. & Air transport & 57.185 & 0,66 & 16,40 \\
\hline 6. & Warehouse and support & 54.983 & 0,63 & 15,77 \\
\hline 7. & Transportation & 348.770 & 4,01 & 100 \\
\hline 8. & Gross Domestic Product (GDP) & 8.695 .000 & 100,00 & \\
\hline
\end{tabular}

Source : BPS, Indonesia 


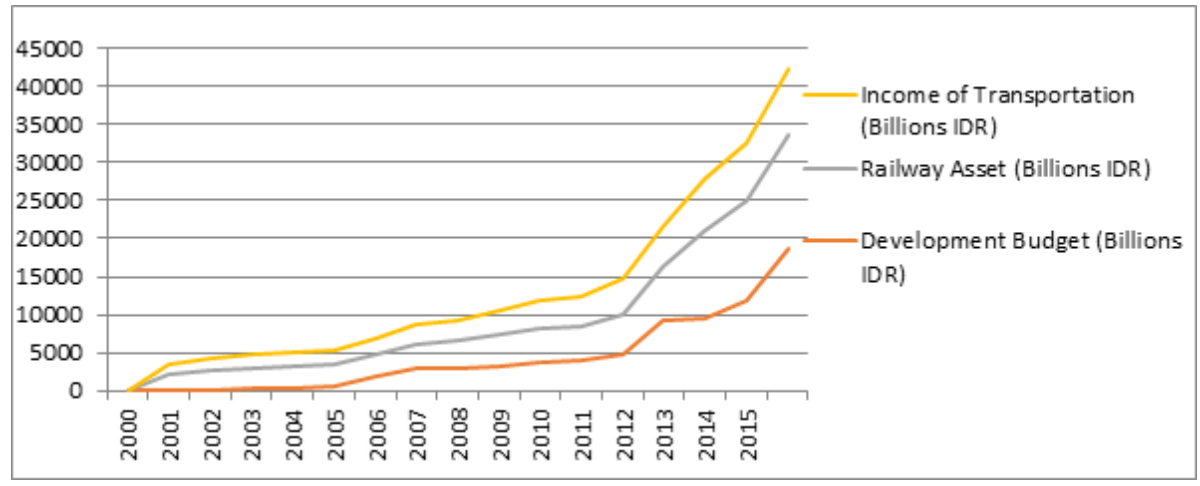

Figure. 1. Graphics of the increment of Development Budget, Railway Asset, and Income

For urban transport, transportation costs have a significant contribution to economic activity, for example in Jabodetabek area, rail transportation gives a very real role. The number of Jabodetabek commuter train passengers in November 2017, averaging 1.1 million passengers a day [1].

As shown in Table 1, The contribution of the transportation sector in the formation of Gross Domestic Product (GDP) is $4.01 \%$, while the railway transportation $0.03 \%$. For the share of transportation mode, road transport dominated by $55.41 \%$, while rail transport was by $0.84 \%$. Despite the fact the value of the contribution of railway transportation sector is low enough, the development of railway in Indonesia shows a significant growth as in fig. 1.

In the period of 2006 to 2016, the average annual growth of passenger transportation is $9 \%$, while the average annual growth of freight transport is $8 \%$ [2]. In essence, the focus of government policy in the field of freight and passenger transportation is to optimize the role of each mode of transportation in an effort to minimize costs and externalities. The policy is carried out through the integration of a number of modes of transportation in accordance with their respective comparative advantages.

This article aims to investigate the role of rail transportation and four other transportation sectors in Indonesian economy for period 2000 - 2010 using Input-Output approach to provide policymakers with a basic picture of the role of rail transportation sector compared with other sectors. The fundamental purpose of I-O approach is to analyse the contribution of each transportation sectors to output of whole transportation sector, analyse the linkage of each sector to other sectors, and analyse the multiplier effect of each transportation sectors to output, income, and employee.

\section{LITERATURE REVIEW}

The I-O analysis could be a good research methodology to explore the influence of railway transportation on the Indonesia economy.

Various research results using I-O analysis have shown good performance in providing policy recommendations, especially to know the linkage between the transportation subsector and its improvement efforts in the national economy.

A study finds empirical evidence of the importance of developing transport infrastructure in accelerating productivity and economic development, particularly for African countries[3]. In line with that Akanbi Bosede, et al.[4] found that transportation infrastructure has a statistically significant and positive relationship with economic growth in Nigeria. This means that improving the transport infrastructure will boost economic growth. 
Rong-Her Chu and Yu-Chang Lin [5] concluded that the relationship of the transport industry in Taiwan is stronger in absorbing related industrial products than the products used as inputs in other industries. Road, rail and air transport have a strong ability to attract other industries. The effects of the transport sector triggered production high enough and increased from $2.80 \%$ in 1991 to $19.41 \%$ in 2006 . The highest effect was road transport whereas the lowest was water transport, but water transport had the highest effect on job creation, followed by the air transport and warehousing sectors.

Transport infrastructure investment in economic development is important as a means to facilitate the mobility of goods and services that facilitate the relationship between remote and growth centers. Smooth flow of goods and services will stimulate economic activity resulting in an increase in household income [6]. Increased production activities in the transportation sector affect the activities in other sectors, so as to provide an increase in the economy of the community. The effectiveness of investment in transport infrastructure to improve the economy and provide benefits to the community depends on the utilization of transportation facilities by producers and consumers as well as the leading sectors.

Jin Wang, Michael B, and Charles [7] studied that the rail and water transport sectors resulted in a significant change in sectoral prices in the energy resources sector. This reflects the high dependence of these sectors on the rail and water transport sectors.

Hideo Fukushi [8] in Thailand resulted there is a growing phenomenon of transportation costs of road transport. This phenomenon leads to shifting modes of transportation from road to other modes. The mode of rail transport is considered as one of the solutions to the problem. The development of rail transport modes and water transport has great potential to boost Thailand's economy through reduced logistics costs.

Tschangho John Kim, et al [9] of the University of Illinois counts and evaluates the impact the damage network as a result of an earthquake as well as the hindrances of the commodity streams against national and regional economy. This uses two different methods of analyses of model I-O multi-regional and model of regional commodity stream. The outcome can be used as a tool to identify the critical part in the transportation network and to analyze the strategy of the after earthquake reconstruction.

Ina Drejer [10] has conducted a research of the characteristics of different attempts to operate the Hirschman original concept in relations with forward and backward with an inception of Rasmussen Dispersion Index and shift into what is called the interrelated measurement of Hirschman-Rasmussen. Empirical analysis employed with input-output Denmark data of the periods of 1966 to 1992 demonstrates a high stability rate from time to time from the individual interrelatedness, yet the key to the industry "power" becomes weak.

Rebecca Bess dan Zoe O. Ambargis [11] states that if input-output model is accurately adopted, the model can be a very beneficial tool to predict the impact of the whole economy from the initial conversion of the economic activities. To enable to use this model effectively, the analyst has to collect detailed information about the project or program being studied. This paper focuses on the information assumption needed to use a comparison of regional input-output accurately, particularly a multiplier yielded in Regional Input - Output Modelling System (RIMS II).

Lismuba Indriani and M. Abdul Mukhyi [12] conduct a research about the top Indonesian economic sector using the approach of I-O with the update data in 2008 of 66 economic sector.

The top sector or key economic sector in Indonesia, there are 12 sectors; namely Trading Sector, Chemical industry, Fertilizers Industry and Pesticides, Others, Property, Machinery 
Industry, Electrical Tools and Equipment, FMCG Industry, Land Transportation, Electricity, Gas, and Clean Water, Plastic and Rubber Industry, Poultry, Pulp and Paper Industry, Carton and Paper Made Goods.

G. Alivelu [13] of Zagreb University makes an analysis of the cost structure in the railways sector in India. In his research, data are gathered from the years of 1981-1982 and 2002-2003 from diverse publications in Railway Board, India Railways Department. Research findings show that the price elasticity of employment is $(0,90 \%)$, fuel is $(1,32 \%)$ and capital is $(2,22 \%)$ against the cost functions. Negative evidences in the cost functions indicate that while the input prices increase, the demand will go down.

Mitsuhiro Hayashi [14] conducted a study that evaluates the achievement of industrialization in Indonesia and clarifies the main challenges existing in sustaining the industrialization employing input-output analysis method. This study finds that the decreases of investment is a pitfall that hinders industrialization and indicates an urgent need to Indonesia to restore the investment environment, specifically to the foreign investors.

Faye Duchin dan Albert E. Steenge [15] verifies about the foundations mathematics for the economic input-output, main model variants, and the underlying economic theory. These features and models make it very compatible in understanding the relationship between economy and environment stressed out around the world. The most important approach in analysing this is by involving comparison, decomposition, and scenario analysis.

\section{METHOD}

The Input-Output analysis is a good research methodology that can be used to explore the influence of the transportation on the national economy. This section briefly introduces the Input-Output analysis used to analyze the inter sector contributions, inter sector linkage and multiplier of the transportation sector in the national economy.

The Input-Output tables from 2000 to 2010 provide comprehensive economic data, covering all commodities and economic activities, both commodities produced by the domestic (domestic) and commodity sectors derived from foreign production (imports). Goods and services or commodities produced by the production sector can consist of a variety of different types and physical forms. In the process of analysis of Table I-O, the researcher performs a step to classify goods and services into certain groups. This process of grouping goods and services is known as sector classification process. In the practice of preparing Table I-O, sector classification is done at an early stage.

The basic balance of the I-O model consisting of 161 sectors can be expressed as

When read in a linearity:

$$
\mathrm{x}_{\mathrm{i} 1}+\mathrm{x}_{\mathrm{i} 2}+\mathrm{x}_{\mathrm{i} 3}+\ldots+\mathrm{x}_{\mathrm{i} 161}+\mathrm{F}_{\mathrm{i}}=\mathrm{X}_{\mathrm{i}}
$$

This equation describes the demand side (demand driven) model as viewed vertically in the I-O table.

When read in a column:

$$
\mathrm{x}_{1 \mathrm{j}}+\mathrm{x}_{2 \mathrm{j}}+\mathrm{x}_{3 \mathrm{j}}+\ldots+\mathrm{x}_{161 \mathrm{j}}+\mathrm{V}_{\mathrm{j}}=\mathrm{X}_{\mathrm{j}}
$$

this equation expresses the supply side (supply driven) model as view horizontally in the I-O table.

Where $x_{i j}$ is the inter-industry purchases of producing sector $i$ from supply sector $j, X_{i}$ is the total gross output in sector $i, F_{i}$ is the final demand in sector $i, V_{j}$ is the final value added by sector $j$. 
The Influence of Railway Development on the Indonesian National Economy: an Input-Output Approach

\section{RESULT AND DISCUSSION}

\subsection{Output and value added Contribution}

In the analysis of the contribution of I-O to 161 sectors, the transport sector can be broken down into the sub-sectors of road transport, rail transport, river, lakes and ferries transportation, sea transport, air transport and other transportation services. In this analysis more focused on the role of each mode of transportation in the national economy shown in Table 2.

In Table 2, it can be seen that in 2000 the road transport occupied the highest rank (38.19\%) and in 2010 increased its contribution to $52.12 \%$. Sea transport is ranked second in 2010 by $11.62 \%$. Air transport starting in 2000 showed an increase, this is because of the ease in the air transport business that is cheap (low cost carrier) so that the mode of air transport is increasingly in demand by the public.

Railway transport had the lowest ranks with a contribution of $1.15 \%$ in 2010 , this shows that the contribution of the train is very low considering the limitations of railway network in Indonesia is limited in Java and Sumatera.

\subsection{Interconnected Linkage}

Based on table 3, it can be seen that the power of spreading and power of sensitivity of mode of railway transportation in the year of 2010 has a different value where the power of spreading is higher than the degree of sensitivity. This indicates that railway transportation mostly uses sectors as an input for a sub railway sector, yet other sectors have not adopted yet as it can be seen from the share lowest railway transportation in comparison with others.

Table 2. Output Contribution and Value Added of Transportation Mode in The National Economy

\begin{tabular}{|l|l|l|l|l|l|l|}
\hline \multirow{2}{*}{ Sector } & Year 2000 & Year 2005 & \multicolumn{2}{|l|}{ Year 2010 } \\
\cline { 2 - 8 } & BLI & FLI & BLI & FLI & BLI & FLI \\
\hline Rail Transport & 0.987622 & 0.99752 & 1.000021 & 1.000129 & 1.051852 & 0.658544 \\
\hline Road Transport & 1.010031 & 1.011563 & 1.009321 & 0.999003 & 0.995036 & 2.556444 \\
\hline Sea transport & 1.00083 & 1.000239 & 1.000336 & 0.998572 & 0.988972 & 0.712509 \\
\hline River, Lake, Ferries & 0.997424 & 0.993312 & 0.998752 & 0.998473 & 0.850148 & 0.686808 \\
\hline air Transport & 1.003333 & 0.992997 & 1.004002 & 0.999981 & 0.761595 & 0.792362 \\
\hline
\end{tabular}

Table 3. Forward and Backward Relationship in Mode Transportation

\begin{tabular}{|l|l|l|l|l|}
\hline No & Modes & $\begin{array}{l}\text { Output Year 2000 } \\
\text { IDR.Billion) }\end{array}$ & $\begin{array}{l}\text { Output Year 2010 } \\
\text { IDR.Billion) }\end{array}$ & $\begin{array}{l}\text { Value Added } \\
\text { (IDR.Billion) }\end{array}$ \\
\hline \multirow{2}{*}{1} & \multirow{2}{*}{ Road Transport } & $48,498.100$ & $280,201.029$ & $137,428.669$ \\
\cline { 3 - 5 } & $38.19 \%$ & $52.12 \%$ & $58.09 \%$ \\
\hline \multirow{2}{*}{2} & \multirow{2}{*}{3} & $2,258.074$ & $6,167.960$ & $2,281.640$ \\
\hline \multirow{2}{*}{3} & $1.78 \%$ & $1.15 \%$ & $0.96 \%$ \\
\hline \multirow{2}{*}{4} & Rail Transport & $4,589.625$ & $16,492.905$ & $6,695.525$ \\
\hline \multirow{2}{*}{5} & Ferries & $3.62 \%$ & $3.07 \%$ & $2.83 \%$ \\
\hline 6 & \multirow{2}{*}{6} & $26,596.337$ & $62,466.287$ & $18,926.170$ \\
\cline { 3 - 5 } & Sea Transport & $20.95 \%$ & $11.62 \%$ & $8.00 \%$ \\
\hline \multirow{2}{*}{ Air Transport } & $25,296.986$ & $115,290.733$ & $38,094.958$ \\
\cline { 3 - 6 } & $19.92 \%$ & $21.44 \%$ & $16.10 \%$ \\
\hline
\end{tabular}




\begin{tabular}{|l|l|l|l|l|}
\hline & & $15.55 \%$ & $10.61 \%$ & $14.02 \%$ \\
\hline
\end{tabular}

Source : I-O Table of indonesia

\subsection{Multiplier Effect}

Multiplier analysis (multiplier) is a measurement of a response or an impact of economic stimulus that covers output multiplier, income multiplier and employment multiplier.

Output multiplier of railway services is 1.63 which means the final demand of railway sector is up to IDR 1 billion, there will be an output of the whole sector of IDR 1.63 billion. If we compare with other transportations, railway transportation will give an output impact of the biggest sectors so that if a railway sector is developed by increasing the carrying capacity, there will be potential to lift up the final demand. The result of multiplier output analysis can be seen in table 4 .

The changes of the final demand of a sector will also definitely upgrade the household income of the whole sector. The degree of multiplication of this can be seen in the multiplier number of income. multiplier in table 5. In table 5, it is indicated that railway transportation services gives a valuable impact of 0,363 which means every increments of railway transportation services subsector earns IDR 1 billion, therefore produces the income of the whole household in economy of the amount of IDR 363 million. Unless there is an increment, the household income in railway will only earn IDR 292 million.

Table 4. Multiplier Value Output of Diverse Transportation mode

\begin{tabular}{|l|l|l|}
\hline No & Sectors & Output Multiplier \\
\hline 1 & Railway Transportation Services & 1.633767 \\
\hline 2 & Land Transportation Services & 1.545518 \\
\hline 3 & Marine Transportation Services & 1.536099 \\
\hline 4 & $\begin{array}{l}\text { River and Crossing Transportation } \\
\text { Services }\end{array}$ & 1.320475 \\
\hline 5 & Air Transportation Services & 1.182932 \\
\hline
\end{tabular}

Source: I-O Table of Indonesia

Table 5. Income Multiplier of Transportation Sector

\begin{tabular}{|c|c|c|c|c|}
\hline No & Sector & $\begin{array}{c}\text { Income } \\
\text { Coefficient }\end{array}$ & $\begin{array}{c}\text { Income } \\
\text { Impact }\end{array}$ & $\begin{array}{c}\text { Income } \\
\text { Multiplier }\end{array}$ \\
\hline 1 & Railway transportation & 0.292 & 0.363 & 1.240 \\
\hline 2 & Land Transportation & 0.161 & 0.233 & 1.446 \\
\hline 3 & Marine Transportation & 0.093 & 0.159 & 1.699 \\
\hline 4 & Marine and Crossing Tansportation. & 0.199 & 0.240 & 1.209 \\
\hline 5 & Air Transportation & 0.135 & 0.159 & 1.178 \\
\hline
\end{tabular}

Source: I-O Table of Indonesia 
The Influence of Railway Development on the Indonesian National Economy: an Input-Output Approach

Table 6. Employment Transportation Sector Multiplier

\begin{tabular}{|l|l|l|l|l|l|}
\hline No. & Sector & $\begin{array}{l}\text { The Number } \\
\text { of } \\
\text { Employment } \\
\text { in 2010 }\end{array}$ & $\begin{array}{l}\text { Coefficient of } \\
\text { Employment } \\
\text { (people/ billion) }\end{array}$ & $\begin{array}{l}\text { Employment } \\
\text { Impact } \\
\text { (people } \\
\text { /billion) }\end{array}$ & $\begin{array}{l}\text { Employment } \\
\text { Multiplier }\end{array}$ \\
\hline 1. & Railway Transport & 44,745 & 7.254 & 9.556 & 1.317 \\
\hline 2. & Road Transport & $1,120,647$ & 3.999 & 6.955 & 1.739 \\
\hline 3. & Sea Transport & 144,906 & 2.320 & 5.323 & 2.294 \\
\hline 4. & $\begin{array}{l}\text { River, Lakes, } \\
\text { Ferries }\end{array}$ & 81,342 & 4.932 & 6.828 & 1.384 \\
\hline 5. & Air Transport & 385,138 & 3.341 & 4.740 & 1.419 \\
\hline
\end{tabular}

Source: Data I-O dan SAKERNAS

The multiplier of railway sector income is worth 1.240 which means that every additional IDR 1.00 the income of employment in the railway transportation will create national income of IDR 1.240. When we compare with other transportations, railway mode of transportation will give an impact to the biggest economic sector followed by sectors of river transportation, and crossing, land transportation sector, marine transportation and aviation transportation. In line with that, railway mode of transportation needs priority in development that gives big income impact for the economic sectors.

The result of the calculations of employment multiplier for the transportation sectors with matrix data computations of $161 \times 161$ can be seen in table 6 . If there is a final increment in the railway demand of IDR 1 billion, it gives an impact to the supply of employment opportunity in the whole sectors of about 9.5 people. If there is no relationship between each sector, the employment opportunity will only go up into 7.254 people of whom they are needed by railway transportation sector. The comparison in the impact of the employment opportunity that appears in the whole sectors railway transportation is 1.317 . This number is said to be employment multiplier, which means if there is an increase in employment opportunity in railway transportation sector of 1 person, it will lift up the employment opportunity in the whole sectors of 1.317 people.

Compared to other modes of transportations, it is clear that railway transportation gives multiplier of employment opportunities in the whole sectors in a high degree which is in a contrast with other modes of transportation of 9.5 people for every increment of final demand of IDR. 1 billion. The same thing applies to an increase of employment sector which possesses coefficient of employment in a highest degree of 7.254 meaning that in every increases of the final demand in the railway transportation of IDR. 1 billion will elevate employment opportunities in the railway sector of 7.254 orang.

In accordance with the analysis results above, it can be argued that if there is an additional investment in the railway sector, it will elevate the income and the welfare of the society members.

\section{CONCLUSION}

In a National Scale, analysis results conducted can be simulated that if there is an investment/ development railway sector of IDR 1 billion, it gives an impact as follows:

a. The number of economic out will go up into IDR 1.633 billion.

b. The income of the society will be higher into IDR. 362.507 million. 
c. The employment opportunity will double up into 9.55 peoples.

Therefore, it is significant for the government to lift up the government budget (APBN) that prioritizes more in the development of railway mode of transportation, both for goods and passengers.

\section{REFERENCES}

[1] G. Anggadwita and W. Dhewanto, "Service innovation in public sector: a case study on PT. Kereta Api Indonesia,” J. Soc. Dev. Sci., vol. 4, no. 7, pp. 308-315, 2013.

[2] I. Purnamasari, "Hubungan struktur sistem pengendalian manajemen dan proses sistem pengendalian manajemen dengan kinerja keuangan perusahaan pada PT. Kereta Api Indonesia (PERSERO)," Fokus Ekon. J. Ilm. Ekon., vol. 4, no. 1, 2009.

[3] S. Boopen, "Transport infrastructure and economic growth: evidence from Africa using dynamic panel estimates," Empir. Econ. Lett., vol. 5, no. 1, pp. 37-52, 2006.

[4] A. Bosede, B. Abalaba, and D. Afolabi, "Transport infrastructure improvement and economic growth in Nigeria," Int. J. Humanit. Soc. Sci. Invent., vol. 2, no. 8, pp. 23-31, 2013.

[5] R.-H. Chiu and Y.-C. Lin, "Applying input-output model to investigate the interindustrial linkage of transportation industry in Taiwan," J. Mar. Sci. Technol., vol. 20, no. 2, p. 173, 2012.

[6] G. Weisbrod and A. Reno, Economic impact of public transportation investment. Citeseer, 2009.

[7] J. Wang and M. B. Charles, "IO based impact analysis: a method for estimating the economic impacts by different transport infrastructure investments in Australia," in Paper contributed to the Australasian Transport Research Forum, Canberra, 2010.

[8] H. Fukuishi, "Input-Output Analysis for Transportation Economy and Logistics," L. Lambert Acad. Publ. AG Co KG, 2010.

[9] T. J. Kim, J. S. Lee, I. Crelling, and E. Kang, "Evaluation of Episodic and Seasonal Emission Controls for Transportation in Illinois," 2002.

[10] I. Drejer, "A Schumpeterian perspective on service innovation," in 9th International Joseph Schumpeter Society Conference, Gainesville, 2002.

[11] R. Bess and Z. O. Ambargis, "Input-output models for impact analysis: suggestions for practitioners using RIMS II multipliers," in 50th Southern Regional Science Association Conference, 2011, pp. 23-27.

[12] L. Indriani and M. A. Mukhyi, "Sektor Unggulan Perekonomian Indonesia: Pendekatan Input-Output," Pros. PESAT, vol. 5, 2013.

[13] G. Alivelu, "The estimation of Indian railway cost function," Zagreb Int. Rev. Econ. Bus., vol. 10, no. 1, pp. 11-32, 2007.

[14] M. Hayashi, "STRUCTURAL CHANGES IN INDONESIAN INDUSTRY AND TRADE: AN INPUT-OUTPUT ANALYSIS," Dev. Econ., vol. 43, no. 1, pp. 39-71, 2005.

[15] D. W. Jorgenson, L. Broersma, R. Inklaar, K. Kratena, and M. P. Timmer, "International Input-Output Association (IIOA)," Econ. Syst. Res., vol. 19, no. 3, 2007. 